\title{
Allelopathic effects of Cochlodinium polykrikoides isolates and blooms from the estuaries of Long Island, New York, on co-occurring phytoplankton
}

\author{
Ying Zhong Tang, Christopher J. Gobler* \\ School of Marine and Atmospheric Sciences, Stony Brook University, Stony Brook, New York 11794-5000, USA
}

\begin{abstract}
The toxic dinoflagellate Cochlodinium polykrikoides forms harmful algal blooms in coastal ecosystems around the world, to the great detriment of fisheries. Here we describe the allelopathic effects of $C$. polykrikoides blooms and strains isolated from east coast estuaries of the United States on natural communities and cultured phytoplankton. The allelopathic effects of C. polykrikoides cultures and blooms on the target microalgal cells included loss of motility, distortion of cell morphology, and 60 to $100 \%$ cell mortality within minutes to $24 \mathrm{~h}$. Allelopathy by C. polykrikoides on target microalgae was dependent on the relative and absolute cell abundance of each species as well as exposure time. The ability of C. polykrikoides cultures to kill target algae connected through a $5 \mu \mathrm{m}$ mesh nylon membrane indicated that the allelopathic agents were extracellular and that direct cellular contact with target cells was not required for C. polykrikoides to exhibit allelopathy. Freezing, heating, sonication, and filtration of $C$. polykrikoides cells led to the complete loss of their allelopathic effect, suggesting that the allelopathic agents were short-lived and dependent on cell viability. Additions of the reactive oxygen species (ROS)-scavenging enzymes peroxidase and catalase into C. polykrikoides cultures eliminated or lessened their allelopathic effects, suggesting ROS-like chemical(s) were responsible for the allelopathy. These results are consistent with bioassays of fish and shellfish larvae with C. polykrikoides, suggesting that its toxicity to fish and shellfish larvae and its allelopathic effects on algae are caused by the same agents. The rapid and strong allelopathic effects exhibited by $C$. polykrikoides suggest allelopathy may facilitate blooms by eliminating competing species.
\end{abstract}

KEY WORDS: Allelopathy $\cdot$ Cochlodinium polykrikoides $\cdot$ Harmful algal blooms $\cdot$ Reactive oxygen species $\cdot$ Toxicity $\cdot$ Physiology $\cdot$ Ecology $\cdot$ Phytoplankton

\section{INTRODUCTION}

Harmful algal blooms (HABs) represent a serious threat to the inhabitants of coastal ecosystems across the globe as they negatively impact marine life, habitats, and economies. Anthropogenic nutrient loading and physical oceanographic processes are known to play a central role in the outbreak of HABs (Paerl 1988, Hallegraeff 1993, Pitcher \& Calder 2000, McGillicuddy et al. 2005, Anderson et al. 2008, Heisler et al. 2008). Biological interactions among the plankton are also important for the development and sustenance of HABs. Among these, the ability or inability of pelagic (Turner
\& Tester 1997, Gobler et al. 2004, Buskey 2008) and benthic grazers (Bricelj \& Shumway 1998, Cerrato et al. 2004, Hegaret et al. 2007) to consume bloom-forming microalgae has been most commonly investigated. Another biological factor, which may strongly influence the dynamics of HABs, but has been less frequently considered, is allelopathy.

Allelopathy has long been known to play a crucial role in the ecology of terrestrial plants (Muller 1966, Putnam \& Duke 1974, Rice 1984, Siqueria et al. 1991). Phytoplankton showing allelopathic effects on other algae, bacteria, and grazers include both freshwater and marine species, particularly diatoms, cyanobacte- 
ria, haptophytes, and dinoflagellates (Legrand et al. 2003, Granéli \& Hansen 2006, Tillmann et al. 2008b). More recently, several phytoplankton species forming HABs have been found to have allelopathic effects on other microalgae (Legrand et al. 2003, Granéli \& Hansen 2006, Tillmann et al. 2008b). Allelopathy has been purported to regulate both phytoplankton community composition and HAB dynamics (Legrand et al. 2003, Granéli \& Hansen 2006, Tillmann et al. 2008b), although, in many cases, the responsible allelochemical agents have not been identified (Legrand et al. 2003, Granéli \& Hansen 2006, Tillmann et al. 2008b). Others suggest allelopathy may be important for HAB maintenance, but not for bloom initiation (e.g. Solé et al. 2006, Jonsson et al. 2009). The allelopathic effects of HABs are often caused by extracellular chemical agents that are different from the chemicals responsible for poisoning humans via shellfish (Tillmann \& John 2002, Legrand et al. 2003, Granéli \& Hansen 2006, Prince et al. 2008, Tillmann et al. 2008b).

Another dinoflagellate that may have allelopathic impacts on microalgae is Cochlodinium polykrikoides. C. polykrikoides has caused ichthyotoxic blooms around the world. In Asia, blooms of C. polykrikoides have been reported in Japan (Iwataki et al. 2008), South Korea (Kim 1998, Kim et al. 1999), the Philippines (Azanza et al. 2008), Malaysia (Anton et al. 2008), Indonesia (Anton et al. 2008), the Arabian Gulf (Richlen et al. 2010), and China (Qi et al. 1993) and have caused hundreds of millions of dollars in fisheries losses (Kim 1998, Kim et al. 1999). In North America, blooms of at least 2 species of Cochlodinium, including C. polykrikoides, have occurred in the United States (Silva 1967, Marshall 1995, Kudela et al. 2008, Tomas \& Smayda 2008), Canada (Whyte et al. 2001), the Caribbean (Margalef 1961), Costa Rica (Guzmán et al. 1990), and Mexico (Gárate-Lizárraga et al. 2004) and have occurred annually since 2004 on both the Pacific and Atlantic coasts (Curtiss et al. 2008, Gobler et al. 2008, Mulholland et al. 2009). The highly lethal effects of these blooms on fish, shellfish, shellfish larvae, and zooplankton and subsequent impacts on fisheries have been well established (Kim et al. 1999, Whyte et al. 2001, Gobler et al. 2008, Jiang et al. 2009, Tang \& Gobler 2009a, b). Studies to date suggest short-lived, labile toxins, similar to reactive oxygen species (ROS), play a central role in the toxicity of C. polykrikoides to fish and shellfish (adult, juvenile, and larvae) (Kim et al. 1999, Jiang et al. 2009, Tang \& Gobler 2009a, b). Both this nature of toxicity and the near-monospecific nature of $C$. polykrikoides bloom patches suggest this species may also have allelopathic effects on competing microalgae. Many harmful algae that are ichthyotoxic are also known to have allelopathic impacts on other algae, including Karenia brevis (Kubanek et al. 2005, Prince et al. 2008),
Prymnesium parvum (Fistarol et al. 2003, Granéli \& Johansson 2003, Tillmann 2003), Alexandrium spp. (Arzul et al. 1999, Tillmann \& John 2002, Fistarol et al. 2004), Chrysochromulina polylepis (Schmidt \& Hansen 2001), and Heterosigma akashiwo (Yamasaki et al. 2009). However, to date, the allelopathic effects of isolates of Cochlodinium species on other microalgae have not been documented. Yamasaki et al. (2007) observed growth inhibition and formation of abnormal cells in Akashiwo sanguinea co-cultured with C. polykrikoides, but allelopathy was clearly excluded from their explanations of the possible causes, since a low-celldensity culture of $C$. polykrikoides connected with a culture of $A$. sanguinea through a $3 \mu \mathrm{m}$ mesh membrane did not exhibit the inhibitory effect. Instead, the observed growth inhibition was interpreted with a mechanism requiring direct cell contact.

Here we present our investigation on the allelopathic impacts of Cochlodinium polykrikoides clones and blooms from Long Island, New York, USA, to various species of phytoplankton (target species) that are indigenous to most coastal waters. Cultures of the target species exposed to or co-cultured with C. polykrikoides and connected to C. polykrikoides cultures through a $5 \mu \mathrm{m}$ mesh exhibited dramatic mortalities and declines in cell densities during short-term exposures $(1 \mathrm{~h}$ to $4 \mathrm{~d})$. A series of experiments are also presented that suggest a possible mechanism of the allelopathic effects observed.

\section{MATERIALS AND METHODS}

Cultures and culturing conditions. Three clones of Cochlodinium polykrikoides, CP1, CPPB12, and CPPB17, were examined for their allelopathic effects on other microalgae. The strains were obtained by pipetting single cells from seawater samples collected during blooms on August 31, 2006 from the most western basin of the Peconic Estuary, Flanders Bay $\left(40.923^{\circ} \mathrm{N}, 72.587^{\circ} \mathrm{W}\right.$; for $\left.\mathrm{CP} 1\right)$ and September 4 , 2008 from Peconic Bay $\left(40.9368^{\circ} \mathrm{N}, 72.5128^{\circ} \mathrm{W}\right.$; for CPPB12 and CPPB17). The isolated single cells were transferred to polystyrene cell culture plates containing sterile GSe culture medium (see below) under an inverted microscope. Identification of all clonal isolates as C. polykrikoides has been confirmed with large subunit (LSU) rDNA sequencing (Gobler et al. 2008, Iwataki et al. 2008). Cells were cultured in sterile GSe medium with a salinity of 32.5 , made with autoclaved and $0.2 \mu \mathrm{m}$ filtered seawater (Doblin et al. 1999). The cultures were maintained at $21^{\circ} \mathrm{C}$ in an incubator with a $12 \mathrm{~h}$ light: $12 \mathrm{~h}$ dark cycle, illuminated by a bank of fluorescent lights that provided a light intensity of $\sim 100 \mu$ mol quanta $\mathrm{m}^{-2} \mathrm{~s}^{-1}$ to cultures. 
The target species (strains) used in the present study included 5 species of dinoflagellates (Akashiwo sanguinea AS2, Gymnodinium aureolum KA2, Gymnodinium instriatum L6, Heterocapsa rotundata MS5, and Scrippsiella cf. trochoidea MS3), a diatom (Thalassiosira weissflogii CCMP1339), a pelagophyte (Aureococcus anophagefferens CCMP1984), a raphidophyte (Chattonella marina Chatt1), a haptophyte (Isochrysis galbana, Tahitian strain; T-Iso), and a cryptophyte (Rhodomonas salina CCMP1319). All CCMP strains were from the Provasoli-Guillard National Center for Culture of Marine Phytoplankton (Maine, USA), while the Chattonella marina (ChatM1) from Singapore coastal waters was kindly provided by M. J. Holmes from the National University of Singapore and I. galbana (T-Iso) was kindly provided by Nichols S. Fisher's laboratory at Stony Brook University. All the other cultures were isolated by Y. Z. Tang from Chesapeake Bay (Virginia, USA; AS2, KA2, L6) or from Shinnecock Bay (New York, USA; MS3 and MS5). All the cultures were maintained under the same conditions as for $C$. polykrikoides cultures.

Since Akashiwo sanguinea was highly sensitive to Cochlodinium polykrikoides in preliminary experiments and easily identified in the co-culture with $C$. polykrikoides, it was used as a model target alga in multiple experiments. In addition, A. sanguinea AS2 and $G$. instriatum L6 were used for bi-algal culture experiments with $C$. polykrikoides, because these species are commonly found co-occurring with C. polykrikoides in the estuaries of the region (Gobler et al. 2007). All cultures used for experiments were in early or mid-exponential phase growth, with high levels of ambient nutrients still present. Additions of GSe medium were made to all experiments, and measured nitrate concentrations were $>100 \mu \mathrm{M}$ during all time points of all experiments. Given that these concentrations are 2 orders of magnitude above the half-saturation constant of nitrate for growth of C. polykrikoides (Gobler et al. unpubl. data), all experiments were performed under nutrient-replete conditions. In addition, $\mathrm{pH}$ levels always ranged between 7.8 and 9.0, in both treatments and control cultures, which were equivalent to or even smaller than the range of changes in $\mathrm{pH}$ in the cultures of C. polykrikoides and the target species, indicating treatment effects were not associated with changes in $\mathrm{pH}$.

Generality of the allelopathic effects of Cochlodinium polykrikoides. To examine whether C. polykrikoides (strain CP1) had allelopathic effects on the co-occurring microalgal species and whether these effects were observable in particular species, 10 species of microalgae from different classes were chosen as target organisms to be co-cultured with $C$. polykrikoides CP1 (final cell density: $2450 \pm 390$ cells ml$^{-1}$, triplicates cultures) in 6-well culture plates for $24 \mathrm{~h}$ under the same conditions used for maintaining cultures. The initial cell biomass of all the target species was biovolume-normalized via dilution with GSe medium. Controls using the identical target cell densities and culture volumes were diluted with GSe medium rather than C. polykrikoides. Initial cell densities (i.e. after being combined with CP1 culture or, for controls only, with GSe medium) in treatments and controls of Aureococcus anophagefferens, Rhodomonas salina, Isochrysis galbana, Thalassiosira weissflogii, Akashiwo sanguinea, Gymnodinium aureolum, Gymnodinium instriatum, Heterocapsa rotundata, Scrippsiella cf. trochoidea, and Chattonella marina were 3.88 $( \pm 0.18) \times 10^{4}, 2.9( \pm 0.27) \times 10^{4}, 1.46( \pm 0.08) \times 10^{4}, 3.66$ $( \pm 0.01) \times 10^{3}, 340 \pm 60,1.18( \pm 0.15) \times 10^{3}, 250 \pm 35,1.24$ $( \pm 0.58) \times 10^{3}, 2.59( \pm 0.20) \times 10^{3}$, and $787 \pm 189$ cells $\mathrm{ml}^{-1}$, respectively. During and at the end of the inoculation, the plates were observed and photographed with a digital SPOT Insight camera mounted on a Nikon Eclipse TS100 inverted microscope (Nikon) to document possible morphological and behavior changes and cell death at 4 and $24 \mathrm{~h}$. The triplicate cultures were fixed with Lugol's solution (final concentration: $2 \%$ ), and cell densities were enumerated with a $0.1 \mathrm{ml}$ phytoplankton counting chamber or a $1.0 \mathrm{ml}$ Sedgewick rafter counting chamber under a compound microscope (each sample of triplicates for a treatment was counted thrice).

Allelopathic effects of multiple strains of Cochlodinium polykrikoides. To determine whether the allelopathic effects observed from C. polykrikoides were a feature specific to strain CP1, experiments were conducted with 2 additional strains of C. polykrikoides: CPPB-12 (targeting Gymnodinium instriatum L6) and CPPB-17 (targeting Akashiwo sanguinea), while strain CP1 was used for positive controls. Using 12-well culture plates, cultures of CP1, CPPB-12 and CPPB-17 were added to triplicate wells along with cultures of A. sanguinea or G. instriatum. Control treatments for each species and strain were also established with GSe medium added in place of the co-culture. The initial cell densities of CP1, CPPB-17, and AS2 were 730, 870, and 40 cells $\mathrm{ml}^{-1}$, respectively, for the first experiment, while initial cell densities of CP1, CPPB-12, and L6 were 185,155 , and 80 cells $\mathrm{ml}^{-1}$, respectively, for the second. Culture plates were incubated using the conditions listed above for $24 \mathrm{~h}$, after which cultures were preserved with Lugol's solution (final concentration: $2 \%$ ) for enumeration.

Dose-dependence of allelopathic effects of Cochlodinium polykrikoides. Experiments examining how the allelopathic effects changed with the cell densities of C. polykrikoides and target species were conducted. Two bi-algal culture experiments were conducted using 
triplicate $200 \mathrm{ml}$ Pyrex Erlenmeyer flasks, each containing either C. polykrikoides CP1 (control), a target species (Akashiwo sanguinea, Gymnodinium instriatum; control), or a mixture of C. polykrikoides CP1 and a target species (treatment). All flasks were incubated under the same conditions used for maintaining cultures, and aliquots of cultures (5 ml each) were preserved with Lugol's solution at time points of $24 \mathrm{~h}$ or up to $48-168 \mathrm{~h}$ at intervals of $24 \mathrm{~h}$ and were enumerated as above. The first experiment was conducted with varying cell densities of $C$. polykrikoides CP1 and $A$. sanguinea: 1000 cells ml ${ }^{-1}$ C. polykrikoides CP1 with 1000, 590, 290, 210, and 130 cells ml $\mathrm{m}^{-1}$ A. sanguinea, or 1000 cells $\mathrm{ml}^{-1} A$. sanguinea with 570, 330, 230, and 110 cells $\mathrm{ml}^{-1} \mathrm{CP} 1$. The second experiment was conducted with 750 cells $\mathrm{ml}^{-1}$ C. polykrikoides (with $640,380,130$, and 80 cells $\mathrm{ml}^{-1}$ G. instriatum) and with 370 cells ml ${ }^{-1}$ C. polykrikoides (with 720 cells $\mathrm{ml}^{-1}$ G. instriatum).

Allelopathic effects of different treatments and fractions of Cochlodinium polykrikoides. To better understand the nature of the allelopathic effects of $C$. polykrikoides on other microalgae, experiments were conducted in which the physiological status of $C$. polykrikoides or the chemical features of C. polykrikoides cultures were manipulated. Specifically, the following treatments of C. polykrikoides CP1 cultures (cell density: $1.15 \times 10^{3}$ cells $\mathrm{ml}^{-1}$ ) were used: heating $\left(100^{\circ} \mathrm{C}\right.$ for $15 \mathrm{~min}$ ) and cooling (to $\left.21^{\circ} \mathrm{C}\right)$; freezing $\left(-80^{\circ} \mathrm{C}\right.$ for $\left.30 \mathrm{~min}\right)$ and thawing at $\left.21^{\circ} \mathrm{C}\right)$; removal of cells by filtration through a $5 \mu \mathrm{m}$ mesh nylon membrane; sonication of cells with a high power sonicator (Ultrasonic Power Corporation; the intactness of cells was checked visually under microscope); and addition of the ROS-scavenging enzymes peroxidase $(2.5 \mu \mathrm{g}$ $\left.\mathrm{ml}^{-1}\right)$ and catalase $\left(1.0 \mathrm{U} \mathrm{ml}^{-1}\right)$ to the culture immediately before the experiment (Tang \& Gobler 2009a). Akashiwo sanguinea at a final cell density of 450 cells $\mathrm{ml}^{-1}$ was co-cultured with CP1 after these treatments (final CP1 cell density or equivalent: 920 cells $\mathrm{ml}^{-1}$ ) or with untreated C. polykrikoides CP1 cultures (final cell density: 920 cells $\mathrm{ml}^{-1}$; positive control) in triplicate $200 \mathrm{ml}$ Erlenmeyer flasks. A monoculture of A. sanguinea at the same final cell density as above was used as a negative control. All flasks were incubated for $24 \mathrm{~h}$ under the same conditions used for culture maintenance, subsequently cultures were preserved with Lugol's solution (final concentration: $2 \%$ ) and cell densities for both $A$. sanguinea and CP1 were enumerated using a Sedgewick rafter counting chamber.

Allelopathic effects of cell-free medium connected to a live culture of Cochlodinium polykrikoides. To explore whether direct contact between C. polykrikoides cells and target cells is needed for C. polykrikoides to impart allelopathic effects, experiments were conducted exposing target cells to the cell-free medium that was connected to an active culture of C. polykrikoides CP1 via a $5 \mu \mathrm{m}$ mesh nylon barrier (Sefar Filtration Inc.). The experiments were performed in a specifically modified plastic (high density polyethylene, HDPE) chamber with 30 compartments $(4 \times 4 \times$ $4 \mathrm{~cm})$, in which pairs of 2 adjacent compartments were separated with $5 \mu \mathrm{m}$ mesh nylon (Tang \& Gobler 2009a). A snap-shut lid for the chamber allowed for UV-sterilization and easy access to all individual compartments at the start and end of all experiments.

Three experiments were conducted with the target species Akashiwo sanguinea (exposure time $72 \mathrm{~h}$ ), Gymnodinium instriatum (exposure time $72 \mathrm{~h}$ ), and Chattonella marina (exposure time $144 \mathrm{~h}$ ). For each experiment, each chamber contained $30 \mathrm{ml}$ of either one of the following 4 cultures in triplicate: CP1 control (in both sides of the 2 membrane-partitioned chambers), the target species control (in both sides of the 2 membrane-partitioned chambers), a bi-algal mixture of CP1 and a target species with cell densities the same as controls (positive control), and the culture of a target species connected to the culture of CP1 through the $5 \mu \mathrm{m}$ membrane. The initial concentrations of A. sanguinea, G. instriatum, and C. marina in the bi-algal mixtures were 640,600 , and 500 cells $\mathrm{ml}^{-1}$, respectively, while the corresponding initial cell concentrations of Cochlodinium polykrikoides CP1 were 1740, 1650, and 900 cells $\mathrm{ml}^{-1}$, respectively. After the cultures were added, the chamber was closed and incubated under the standard conditions listed above. After incubation, the cultures were gently mixed, and pipetted simultaneously from both sides by 2 people, ensuring that the rate of culture removal was identical for each side. Samples were fixed with Lugol's solution (final concentration: $2 \%$ ) and microscopically enumerated using a Sedgewick rafter counting chamber.

Natural algal population experiments. Two experiments were conducted with Cochlodinium polykrikoides bloom water or non-bloom water to observe the allelopathic effects of $C$. polykrikoides cultures and blooms within a natural phytoplankton community. For the experiment with bloom water, a surface bloom (with a C. polykrikoides cell density of 2700 cells ml $^{-1}$ ) was sampled from Peconic Bay, Long Island, New York, USA, on September 2, 2009. In a $200 \mathrm{ml}$ sterile flask, $10 \mathrm{ml}$ of Akashiwo sanguinea culture (final concentration: 10 cells $\mathrm{ml}^{-1}$ ) was mixed with $40 \mathrm{ml}$ of bloom water as a treatment. Two more aliquots of A. sanguinea culture were mixed with either GSe medium or $0.2 \mu \mathrm{m}$ filtered (Steriflip; Millipore) bloom water as controls. After gentle through-mixing, triplicate $10 \mathrm{ml}$ aliquots were transferred into $12 \mathrm{ml}$ wells of 6 -well plates (Corning) and incubated under standard conditions for $24 \mathrm{~h}$. Triplicate $10 \mathrm{ml}$ aliquots were also 
preserved with Lugol's solution (final concentration: $2 \%$ ) at the start of experiments and after $24 \mathrm{~h}$ incubation for enumeration of cell concentrations. The salinities of bloom water and A. sanguinea culture were 29 and 32 , respectively.

For the experiment with non-bloom water, surface water was sampled on August 22, 2009 from Old Fort Pond (OFP), a tidal tributary of Shinnecock Bay, Long Island. In triplicate $200 \mathrm{ml}$ sterile flasks, a $50 \mathrm{ml}$ aliquot of a Cochlodinium polykrikoides CP1 culture (final cell density: 2100 cells $\mathrm{ml}^{-1}$ ) was combined with $50 \mathrm{ml}$ seawater from OFP as the treatment. The C. polykrikoides culture and natural community were both mixed with $50 \mathrm{ml}$ of $0.2 \mu \mathrm{m}$ mesh filtrated OFP seawater as 2 distinct controls. After gentle mixing, triplicate $10 \mathrm{ml}$ aliquots of each treatment were transferred into $12 \mathrm{ml}$ wells of 6-well plates, which were then incubated under standard conditions for $24 \mathrm{~h}$. Initial and $24 \mathrm{~h}$ samples were preserved with Lugol's solution for enumeration of the 6 most abundant microphytoplankton: the diatoms Skeletonema cf. costatum, Chaetoceros sp. and Thalasiossira sp., the flagellate Euglena sp., and the dinoflagellates Gyrodinium sp. and Scrippsiella sp. The salinities of seawater and culture were 30 and 32, respectively, measured before the experiment.
Statistics. One-way ANOVAs and $t$-test were performed to assess the effects of different treatments of Cochlodinium polykrikoides cultures (e.g. concentrations, direct or indirect exposure, live or killed cultures, addition of enzymes) and/or the duration of exposure to C. polykrikoides cells. All percentage data were arcsine square root-transformed before performing ANOVA. Differences among treatments were generally assessed with Holm-Sidak post hoc pairwise comparisons using SigmaStat 3.1. In all cases, significance levels were set at $\mathrm{p}<0.05$.

\section{RESULTS}

\section{Allelopathic effects on competing species}

Cochlodinium polykrikoides CP1 exhibited strong allelopathic effects on all target species examined (Figs. $1 \& 2$ ). The specific effects include loss of flagella and thus motility (for flagellates Akashiwo sanguinea, Gymnodinium aureolum, Gymnodinium instriatum, Heterocapsa rotundata, Scrippsiella cf. trochoidea, and Chattonella marina), change of cellular morphology into a round shape (Rhodomonas salina,
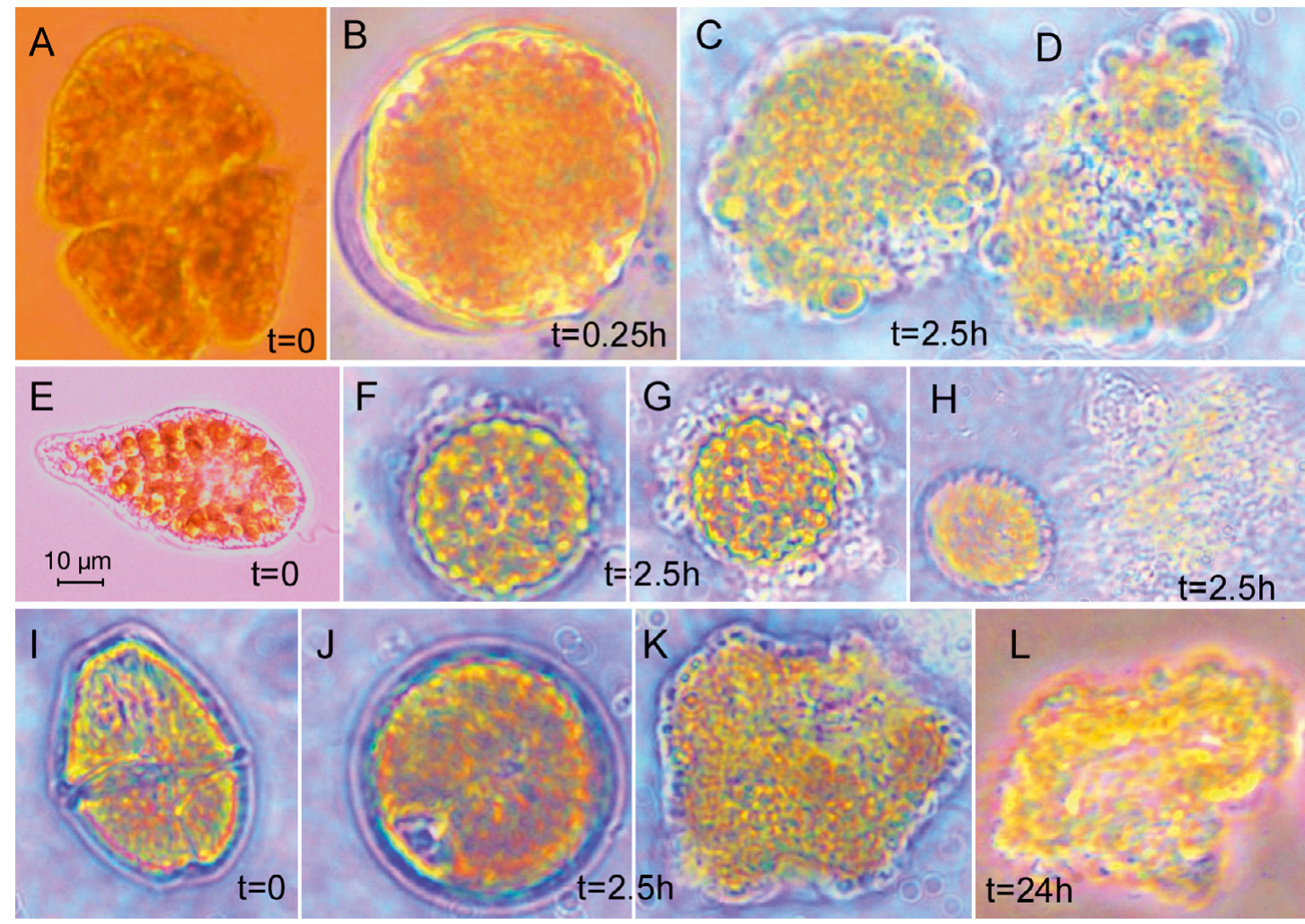

Fig. 1. (A to D) Akashiwo sanguinea, (E to H) Chattonella marina, and (I to L) Gymnodinium instriatum. Morphology of selected target microalgae during exposure to Cochlodinium polykrikoides CP1: (A,E,I) normal cells, (B,F,J) cells that have lost flagella and motility and changed shape in general, $(\mathrm{C}, \mathrm{G}, \mathrm{K})$ substantially deformed cells, and $(\mathrm{D}, \mathrm{H}, \mathrm{L})$ lysed cells. Exposure time $(\mathrm{t})$ is as shown 


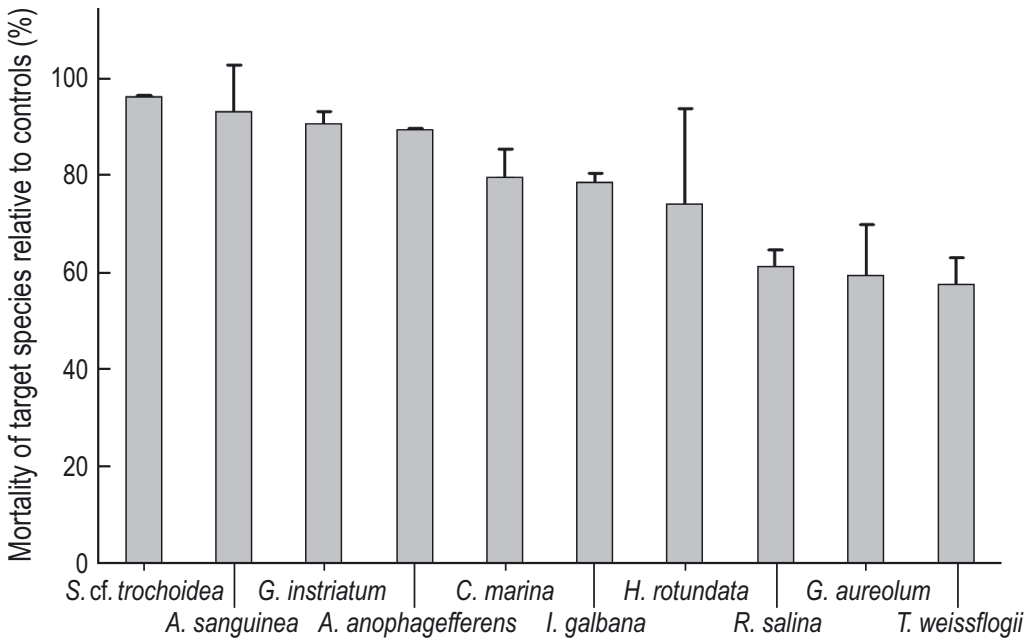

Fig. 2. Percent cell mortality of 10 target species (Scrippsiella cf. trochoidea, Akashiwo sanguinea, Gymnodinium instriatum, Aureococcus anophagefferens, Chattonella marina, Isochrysis galbana, Heterocapsa rotundata, Rhodomonas salina, Gymnodinium aureolum, Thalassiosira weissflogii) co-cultured with Cochlodinium polykrikoides CP1 $\left(2450 \pm 390\right.$ cells ml $\left.^{-1}\right)$ for $24 \mathrm{~h}$, expressed as the percent mortalities of the target cells relative to their respective controls. Error bars: +1 standard deviation of $n=3$

A. sanguinea, G. aureolum, G. instriatum, H. rotundata, S. cf. trochoidea, and C. marina), and eventual cell disintegration and lysis (Fig. 1). These effects were observed in $15 \mathrm{~min}$ in some A. sanguinea cells, but took hours in other species (Fig. 1). After 24 h, C. polykrikoides CP1 at densities of 2450 cells $\mathrm{ml}^{-1}$ caused mortalities in Aureococcus anophagefferens, R. salina, Isochrysis galbana, Thalassiosira weissflogii, A. sanguinea, G. aureolum, G. instriatum, H. rotundata, S. cf. trochoidea, and C. marina of 90, 61, 79, 57, $93,59,91,74,96$, and $79 \%$ compared to control cultures, respectively ( $<<0.001$; Fig. 2). These results demonstrated that the allelopathic effects of $C$. polykrikoides were not specific to any species or class of algae, although some species (A. anophagefferens, A. sanguinea, G. instriatum, S. cf. trochoidea) exhibited greater sensitivity ( $\geq 90 \%$ mortality) than others (R. salina, I. galbana, T. weissflogii, G. aureolum, $H$. rotundata, C. marina; 57 to $79 \%$; Fig. 2).

\section{Allelopathic effects of different strains}

In experiments using different strains of Cochlodinium polykrikoides (CP1, CPPB-12, and CPPB17) and the target species Akashiwo sanguinea and Gymnodinium instriatum, both strains CP1 (730 cells $\mathrm{ml}^{-1}$ ) and CPPB-17 (870 cells ml ${ }^{-1}$ ) caused $100 \%$ cell mortality in A. sanguinea in $24 \mathrm{~h}$ (Fig. 3A), while both strains CP1 (185 cells ml ${ }^{-1}$ ) and CPPB-12 (155 cells $\mathrm{ml}^{-1}$ ) caused significantly higher cell mortality in $G$. instriatum compared to control cultures after $24 \mathrm{~h}$
(67 and $35 \%$, respectively; $\mathrm{p}<0.001, t$-test; Fig. 3B). These results demonstrated that the allelopathic effects exhibited in C. polykrikoides are not strain-specific among strains isolated from different years and locations in New York.

\section{Effects of cell densities and exposure time}

In bi-algal cultures of Cochlodinium polykrikoides (110 to 1000 cells $\mathrm{ml}^{-1}$ ) and Akashiwo sanguinea (1000 cells $\mathrm{ml}^{-1}$ ), the cell mortality of $A$. sanguinea increased dramatically (ANOVA, $\mathrm{p}<0.001$ ) with increasing density of C. polykrikoides (Fig. 4A). For example, C. polykrikoides at 330 cells ml $^{-1}$ caused mortality of $\sim 40 \%$ of $A$. sanguinea cells after $24 \mathrm{~h}$, while 1000 cells ml ${ }^{-1}$ caused $80 \%$ mortality (Fig. 4A). In bi-algal cultures with C. polykrikoides densities fixed at 1000 cells ml ${ }^{-1}$, the mortality of A. sanguinea increased significantly (ANOVA, $\mathrm{p}<0.001$ ) with decreasing $A$. sanguinea cell density, reaching $100 \%$ when the cell density of $A$. sanguinea was $\leq 290$ cells ml ${ }^{-1}$ (Fig. 4B). Hence, these allelopathic ef-
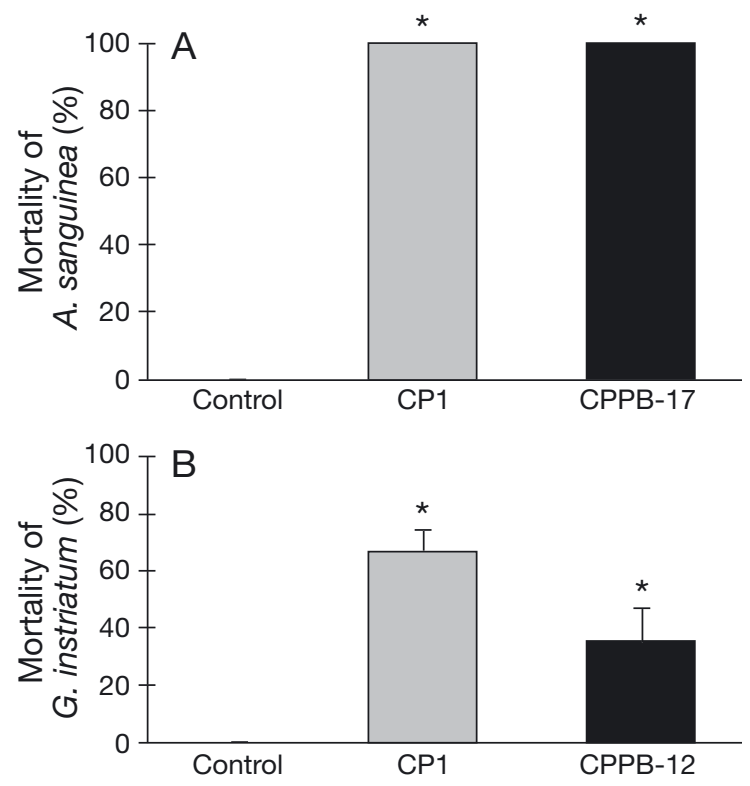

Fig. 3. (A) Percent cell mortality of Akashiwo sanguinea during $24 \mathrm{~h}$ co-culture with Cochlodinium polykrikoides strains $\mathrm{CP} 1$ and CPPB-17 relative to the $A$. sanguinea control. The average initial cell concentrations of CP1, CPPB17, and $A$. sanguinea were 730,870 , and 40 cells ml $^{-1}$. (B) Percent cell mortality of Gymnodinium instriatum in $24 \mathrm{~h}$ co-cultured with C. polykrikoides strains CP1 and CPPB-12 relative to the $G$. instriatum control. The average initial cell concentrations of CP1, CP12, and G. instriatum were 185, 155, and 80 cells ml-1. Asterisks: significant differences $(\mathrm{p}<0.05)$ between treatments and control; error bars: +1 standard deviation of $n=3$ 

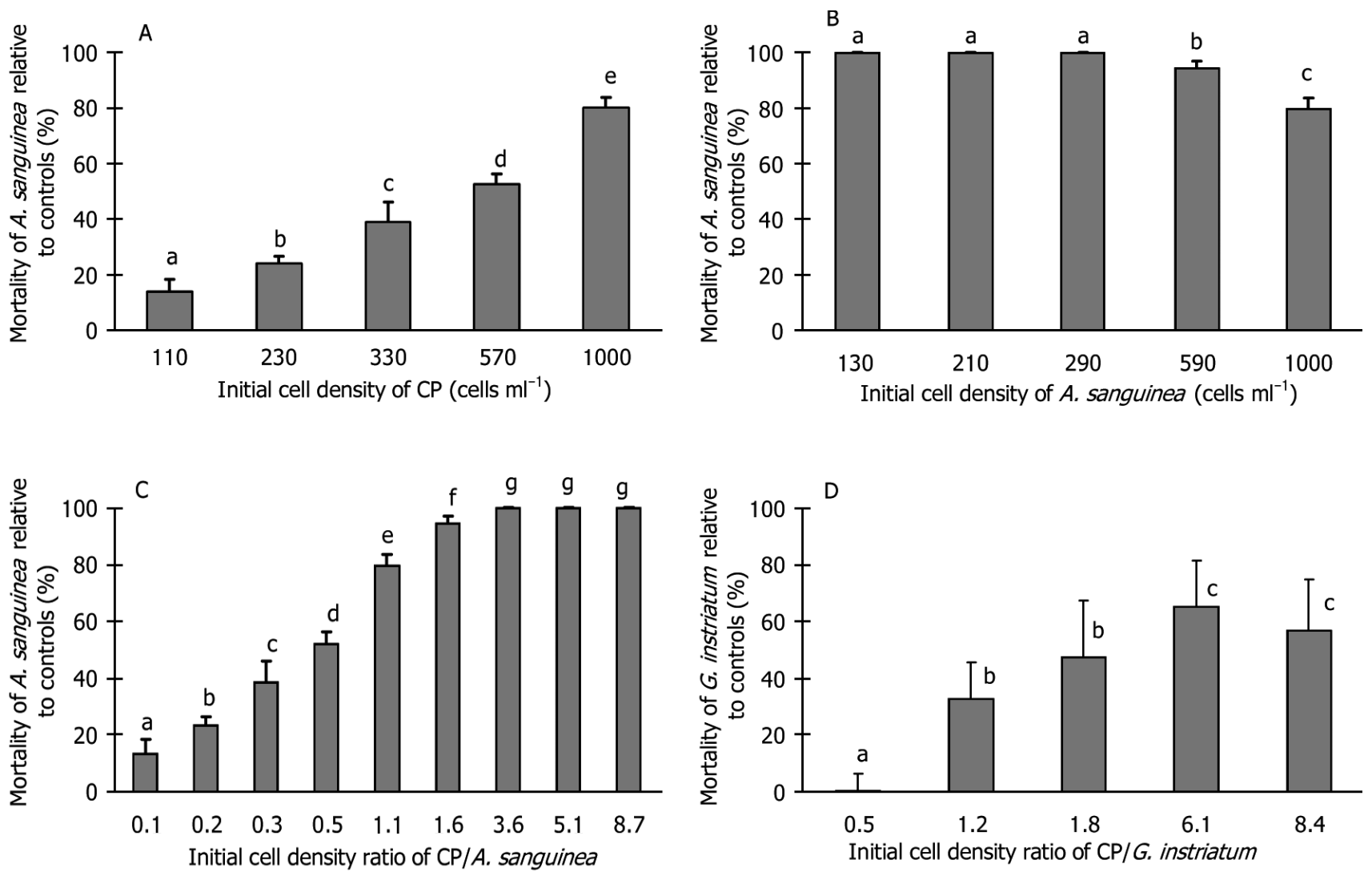

Fig. 4. Percent cell mortality of the target species (Akashiwo sanguinea, Gymnodinium instriatum) compared to the respective controls as a function of the initial cell densities of Cochlodinium polykrikoides (strain CP1), A. sanguinea, and the ratio of $C$. polykrikoides to the target species in bi-algal cultures. (A) A. sanguinea was fixed $\left(1000 \mathrm{cells} \mathrm{ml}^{-1}\right)$ and C. polykrikoides varied (110 to 1000 cells ml ${ }^{-1}$ ) over $24 \mathrm{~h}_{\text {; }}(\mathrm{B})$ C. polykrikoides was fixed $\left(1000 \mathrm{cells} \mathrm{m}^{-1}\right)$ and $A$. sanguinea varied (130 to $\left.1000 \mathrm{cells} \mathrm{ml}^{-1}\right)$ over $24 \mathrm{~h}_{;}(\mathrm{C})$ C. polykrikoides and A. sanguinea, with initial cell densities that varied $\left(1000 \mathrm{cells} \mathrm{ml}^{-1}\right.$ C. polykrikoides vs. 130 to 1000 cells ml $\mathrm{m}^{-1}$ A. sanguinea and 1000 cells ml $^{-1}$ A. sanguinea vs. 110 to 570 cells ml $^{-1}$ C. polykrikoides) and $24 \mathrm{~h} \mathrm{culturing;}$ (D) C. polykrikoides and G. instriatum, with initial cell densities that varied ( 750 cells $\mathrm{ml}^{-1}$ C. polykrikoides vs. 640, 380, 130, and 80 cells ml ${ }^{-1}$ G. instriatum and 370 cells ml ${ }^{-1}$ C. polykrikoides vs. 720 cells ml ${ }^{-1}$ G. instriatum) and $24 \mathrm{~h}$ culturing. Each data point was calculated from the mean of treatments $(n=3)$ and their corresponding controls $(n=3)$. Error bars: +1 standard deviation of $\mathrm{n}=3$; different lower case letters indicate significant differences $(\mathrm{p}<0.05)$ among treatments

fects depended on the absolute cell density of both $C$. polykrikoides and A. sanguinea (Fig. 4A, B), with the percent cell mortality of $A$. sanguinea increasing hyperbolically with the ratio of $C$. polykrikoides:A. sanguinea cells (Fig. 4C). A. sanguinea displayed nearly $100 \%$ mortality when the ratio of $C$. polykrikoides: A. sanguinea exceeded 1.0 (ANOVA, p < 0.001; Fig. 4C). A second experiment conducted with C. polykrikoides and the target species G. instriatum demonstrated a similar dependence of the allelopathic effects on the initial ratio of C. polykrikoides:G. instriatum (Fig. 4D). At C. polykrikoides:A. sanguinea ratios exceeding 2 , there was $>50 \%$ mortality in G. instriatum, whereas at ratios of 1.2 and 0.5 , compared to the control, 33 and $0 \%$, respectively, of G. instriatum cells were lost (Fig. 4C).

The allelopathic effects of Cochlodinium polykrikoides also depended on exposure time. With initial concentrations of C. polykrikoides and Akashiwo sanguinea at 800 and 500 cells $\mathrm{ml}^{-1}$, respectively, cell mortality in A. sanguinea, which was calculated in comparison with the control, significantly increased from 60 to $95 \%$ with an increase in exposure time from 1 to $7 \mathrm{~d}$ (ANOVA, $\mathrm{p}<0.001$; Fig. 5). There was no significant change in C. polykrikoides cell densities over this time frame.

\section{Effects of direct/indirect cell contact}

Cultures of Cochlodinium polykrikoides CP1 separated from target algae with $5 \mu \mathrm{m}$ mesh nylon membranes exhibited significant allelopathic effects on Akashiwo sanguinea, Gymnodinium instriatum, and Chattonella marina (ANOVA, p $<0.001$; Fig. 6). Dur- 


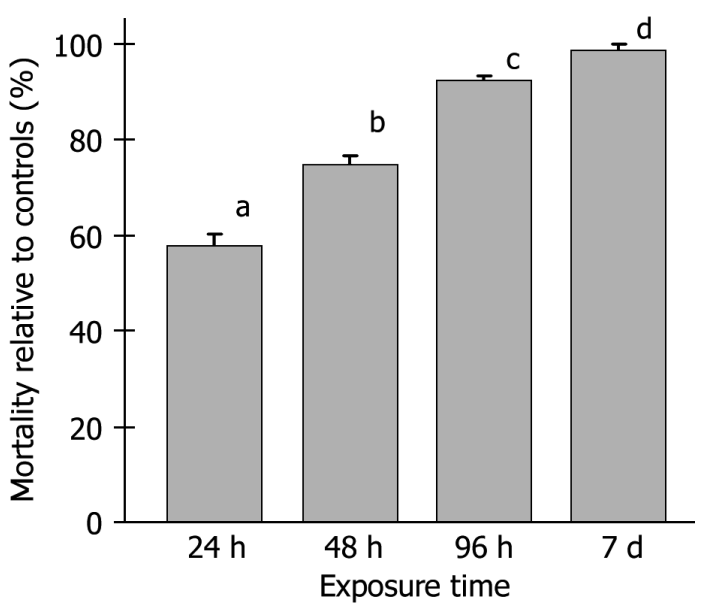

Fig. 5. Percent cell mortality of the target species Akashiwo sanguinea relative to the respective controls (\%) as a function of the exposure (co-culturing) time of A. sanguinea to Cochlodinium polykrikoides CP1. The initial cell densities of CP1 and $A$. sanguinea were 800 and 500 cells ml ${ }^{-1}$, respectively. Each data point was calculated from the mean of treatments $(\mathrm{n}=3)$ and their corresponding controls $(\mathrm{n}=3)$. Error bars: +1 standard deviation of $n=3$; different lower case letters indicate significant $(p<0.05)$ differences among treatments

ing a $72 \mathrm{~h}$ exposure of 640 cell ml-1 of $A$. sanguinea to 1740 cells $\mathrm{ml}^{-1}$ of $\mathrm{CP} 1$, cell densities of $A$. sanguinea declined to 130 cells $\mathrm{ml}^{-1}$, while indirect exposure (5 $\mathrm{mm}$ mesh nylon; Fig. 6) led to a decrease to 540 cells $\mathrm{ml}^{-1}$, which is significantly higher than with the direct exposure (ANOVA Holm-Sidak post hoc pairwise comparison, $\mathrm{p}<0.001$ ), but significantly lower than the negative control $\left(710\right.$ cells $\mathrm{ml}^{-1}$; ANOVA Holm-Sidak post hoc pairwise comparison, $\mathrm{p}<0.001$ ). Direct exposure of C. marina $(475$ cells $\mathrm{ml}^{-1}$ ) to CP1 (1780 cells ml-1) led to a decrease in the concentration of C. marina to 206 cells $\mathrm{ml}^{-1}$, while the indirect exposure led to growth of $C$. marina to 2400 cells $\mathrm{ml}^{-1}$, which was significantly less than that of the negative control of C. marina (3360 cells $\mathrm{ml}^{-1}$; ANOVA Holm-Sidak post hoc pairwise comparison, $\mathrm{p}<0.001$; Fig. 6). Similarly, direct exposure of G. instriatum (600 cells $\mathrm{ml}^{-1}$ ) to CP1 (1420 cells $\mathrm{ml}^{-1}$ ) for $72 \mathrm{~h}$ led to a slight increase of $G$. instriatum to 780 cells $\mathrm{ml}^{-1}$, while the indirect exposure led to growth of $G$. instriatum to 1280 cells $\mathrm{ml}^{-1}$, which was significantly higher than that of the direct exposure, but significantly less than that of the negative control of G. instriatum (1570 cells $\mathrm{ml}^{-1}$; ANOVA HolmSidak post hoc pairwise comparison, p <0.001; Fig. 6). All the above results indicated that direct contact between $C$. polykrikoides cells and the cells of target species is not necessary for C. polykrikoides to have an allelopathic effect and that at least some of the allelochemicals responsible are released from cells of C. polykrikoides, although direct exposure of target species to $C$. polykrikoides caused a much stronger effect on target species.

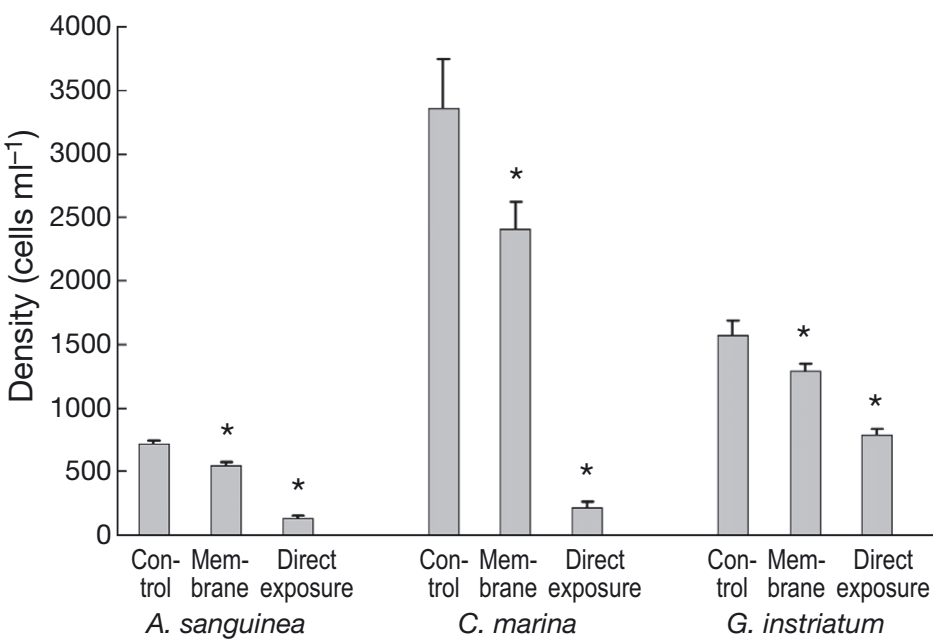

Fig. 6. Cell densities of Akashiwo sanguinea, Chattonella marina, and Gymnodinium instriatum following co-culturing with direct and indirect exposure to Cochlodinium polykrikoides CP1 via a $5 \mu \mathrm{m}$ nylon mesh for $72 \mathrm{~h}$. Concentrations of each target species (A. sanguinea, $C$. marina, and G. instriatum) were constant in the negative control (target species only, the indirect treatment (membrane partitioned), and the direct exposure (mixed culture). Concentrations of C. polykrikoides in the treatment chamber and in the mixed culture were the same for each test species. Error bars: +1 standard deviation of $n=3$; asterisks: significant difference $(p<0.05)$ from the control and between the direct and indirect exposures

\section{Effects of pre-treatment of Cochlodinium polykrikoides and addition of enzymes}

Cochlodinium polykrikoides CP1 cultures at 920 cells $\mathrm{ml}^{-1}$ completely lost their toxicity or allelopathic effects on Akashiwo sanguinea (with an initial cell density of 450 cells $\mathrm{ml}^{-1}$ ) zsonication, and filtration (cell-free culture medium). Final cell densities of $A$. sanguinea in each of these treatments were not different from the negative control (without C. polykrikoides) (ANOVA post hoc comparison, p > 0.05; Fig. 7). In contrast, $98 \%$ A. sanguinea cells in the positive control culture lysed after $24 \mathrm{~h}$ exposure to untreated C. polykrikoides cells (Fig. 7). The addition of $2.5 \mu \mathrm{g} \mathrm{ml} \mathrm{m}^{-1}$ of peroxidase (final concentration) to the experimental cultures mitigated this impact, as there was no significant difference in the final cell density of $A$. sanguinea between this treatment and the negative control cultures (ANOVA post hoc comparison, $\mathrm{p}>0.05$; Fig. 7). The addition of catalase $\left(1.0 \mathrm{U} \mathrm{ml}^{-1}\right)$ yielded a final cell density of $A$. sanguinea that was significantly higher than the positive control (ANOVA post 


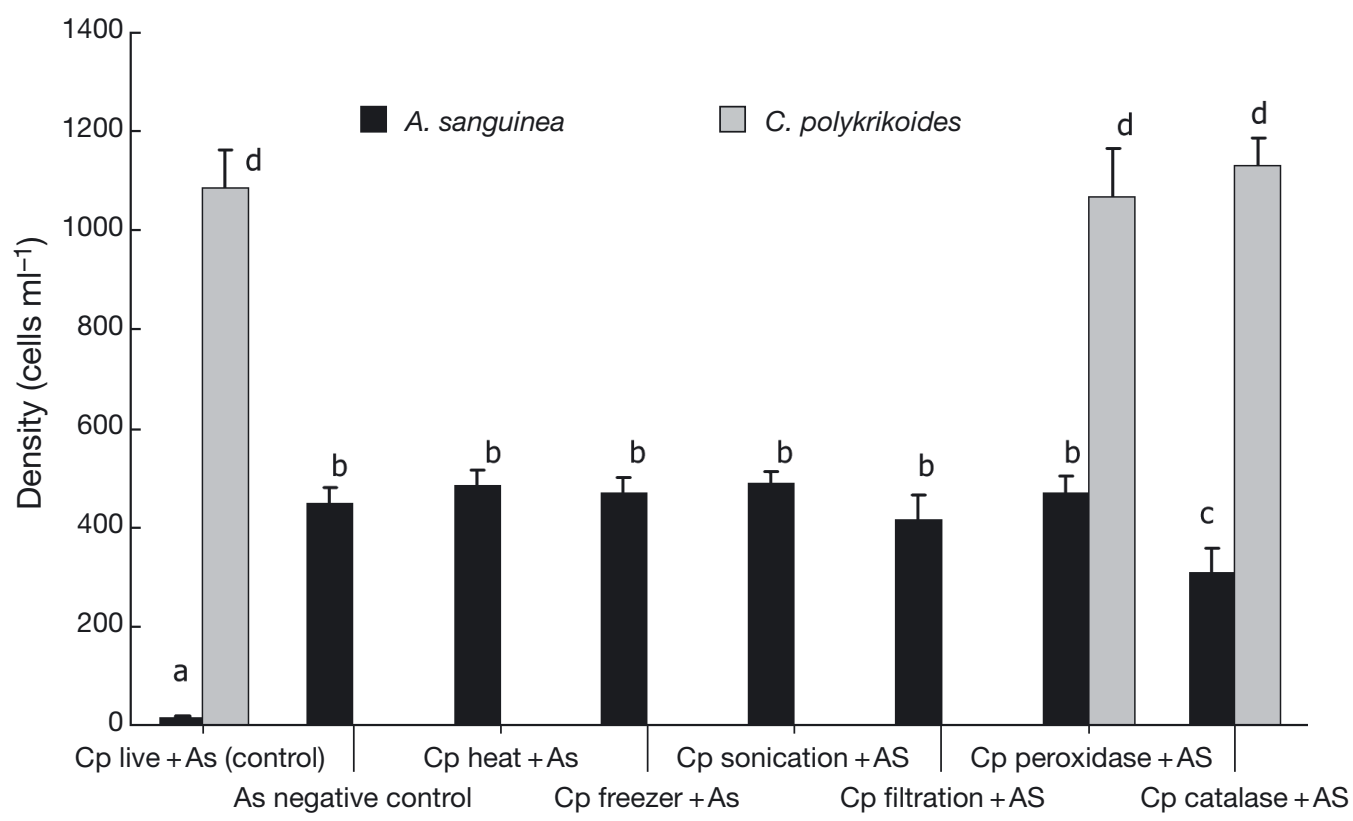

Fig. 7. Cell densities of Akashiwo sanguinea (As) and Cochlodinium polykrikoides CP1 (Cp) after heating (100 ${ }^{\circ} \mathrm{C}$ for 15 min), freezing $\left(-80^{\circ} \mathrm{C}\right)$, sonication, filtration (through $5 \mu \mathrm{m}$ mesh membrane), and with additions of peroxidase (final concentration: $2.5 \mu \mathrm{g} \mathrm{ml}^{-1}$ ) or catalase (final concentration: $1.0 \mathrm{U} \mathrm{ml}^{-1}$ ). Error bars: +1 standard deviation of $\mathrm{n}=3$; different lowercase letters: significant differences $(\mathrm{p}<0.05)$

hoc comparison, $\mathrm{p}<0.001$; Fig. 7), but significantly lower than the negative control (ANOVA post hoc comparison, $\mathrm{p}<0.001$; Fig. 7), i.e. addition of catalase removed most, but not all, of the allelopathic effects of C. polykrikoides on A. sanguinea. There was no significant difference in cell density of $C$. polykrikoides CP1 among the positive control and the mixed cultures with addition of peroxidase or catalase (Fig. 7). A. sanguinea cultures grown with and without these enzymes at these concentrations yielded nearly identical cell densities (ANOVA post hoc comparison, $\mathrm{p}>0.05$ ).

\section{Allelopathic effects of Cochlodinium polykrikoides on natural phytoplankton communities}

Akashiwo sanguinea cells added to a natural sample collected during a bloom of Cochlodinium polykrikoides from the Peconic Estuary experienced significant mortality $(76 \%)$, A. sanguinea did not grow in the bloom water filtrate control, but doubled in cell density in the GSe medium control (ANOVA post hoc pairwise comparison, $\mathrm{p}<0.001$; Fig. 8). During $24 \mathrm{~h}$ exposure of a natural phytoplankton community to a culture of C. polykrikoides CP1 (2100 cells ml ${ }^{-1}$ ), 5 of the 6 most abundant phytoplankton species (Chaetoceros sp., Gyrodinium sp., Scrippsiella sp., Skeletonema costatum, and Thalasiossira sp.) exhibited significantly lower cell densities compared to the control treatment $(\mathrm{p}<0.001, t$-test; Fig. 9). The single exception to this trend was Euglena sp., which achieved higher cell densities in the presence of the $C$. polykrikoides culture $(\mathrm{p}<0.001$, $t$-test; Fig. 9).

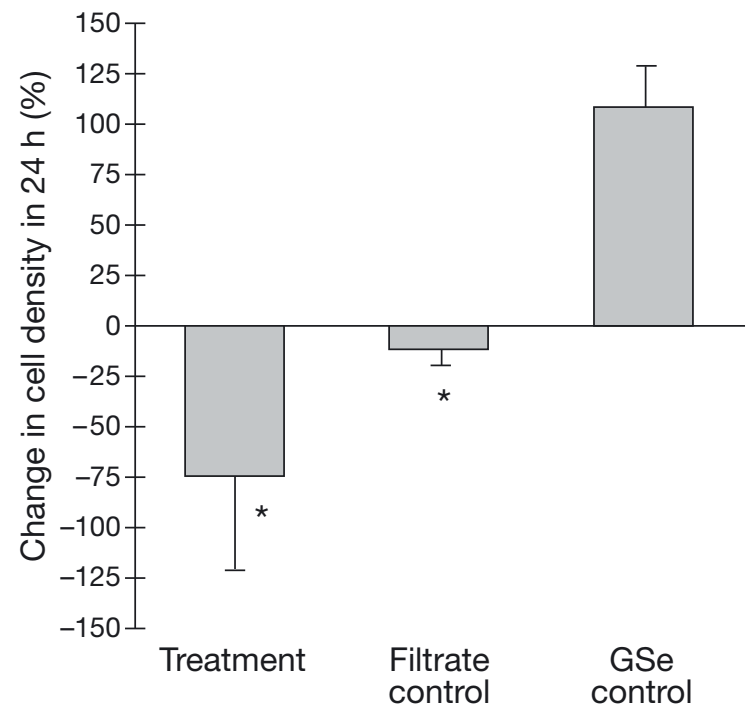

Fig. 8. Percent change in cell densities of Akashiwo sanguinea co-cultured with Cochlodinium polykrikoides bloom water from the Peconic Estuary for $24 \mathrm{~h}$. Cultures of A. sanguinea cultured in either GSe medium or $0.2 \mu \mathrm{m}$ mesh filtrated bloom water were used as controls. Asterisks: significant differences $(p<0.05)$ between treatment and controls or between 2 controls in percent change in cell densities in $24 \mathrm{~h}$ incubation; error bars: \pm 1 standard deviation of $n=3$ 


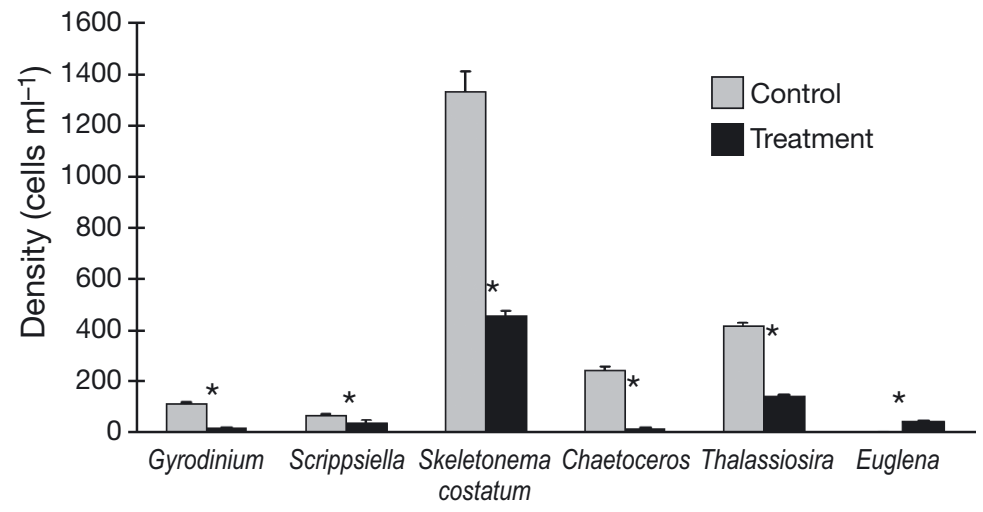

Fig. 9. Cell densities of dominant species present in the water from Old Fort Pond, co-cultured with Cochlodinium polykrikoides CP1 and with $0.2 \mu \mathrm{m}$ mesh filtered C. polykrikoides culture medium after $24 \mathrm{~h}$ incubation. Asterisks: significant differences $(\mathrm{p}<0.05)$ between treatment and control in cell density for each species; error bars: +1 standard deviation of $n=3$

\section{DISCUSSION}

\section{Possible mechanisms and chemical nature of the allelopathic effects}

The present study demonstrates that clonal cultures and blooms of Cochlodinium polykrikoides from the coast of the northeastern United States have highly toxic and inhibitory effects on a variety of common phytoplankton species from multiple classes. The observations suggest the allelopathic effects of C. polykrikoides are broad and not specific to any particular taxon of microalgae. The allelopathic effects on some species were observable within minutes, and included loss of motility, change of cell morphology, and cell lysis and cell death occurred within hours, characteristics categorized as 'acute toxicity' according to Tillmann et al. (2008b). The allelopathic effects depended on the absolute and relative cell abundance of $C$. polykrikoides (i.e. high absolute and relative abundances of $C$. polykrikoides yielded higher mortalities in target phytoplankton) and the exposure time (i.e. longer co-culturing caused higher mortality in the cells of target species). Treatments of heating, freezing, sonication, and filtration for the culture of C. polykrikoides led to significant or complete loss of its allelopathic effects on Akashiwo sanguinea, suggesting that the allelopathic potency depends on viability (or physiological activity) of C. polykrikoides cells, and the agents responsible were highly short-lived. The allelopathic effects exhibited by C. polykrikoides cultures connected with the culture of target species (A. sanguinea, Chattonella marina, or Gymnodinium instriatum) through a $5 \mu \mathrm{m}$ mesh membrane indicated that $C$. polykrikoides produces allelopathic agents that could be released and dissolved in culture medium. Therefore, although direct contact between C. polykrikoides cells and target cells maximizes allelopathic effects, direct contact is not a requisite condition for $C$. polykrikoides to exhibit allelopathy. Yamasaki et al. (2007) reported that direct cell contact between $C$. polykrikoides and $A$. sanguinea was required for the growth-inhibitory and morphological effects observed in A. sanguinea cells and thus excluded allelopathy as a mechanism. Yamasaki et al. (2007) reported the absence of an allelopathic effect in the cell-free medium that was connected with an active $C$. polykrikoides culture (100 cells ml $\left.{ }^{-1}\right)$ through a $3.0 \mu \mathrm{m}$ mesh membrane. We have found that this density of C. polykrikoides is too low to elicit an allelopathic effect in other species (data not shown). Additionally, the smaller and different membrane may not have permitted C. polykrikoides allelochemicals to diffuse in the same manner as our $5 \mu \mathrm{m}$ nylon mesh did.

The removal of allelopathic effects by addition of the ROS-scavenging enzymes peroxidase and catalase into Cochlodinium polykrikoides cultures implies that ROS-like chemicals (e.g. $\mathrm{O}_{2}^{-}, \mathrm{OH} \cdot \mathrm{HO}_{2}{ }^{-}, \mathrm{ROO}^{-}$) are responsible for the alga-killing effect of C. polykrikoides. The loss of toxicity of C. polykrikoides following heating, freezing, sonication, and filtration, and the reduced, but still measurable, toxicity of cultures partitioned with nylon mesh membrane collectively indicate that allelopathic chemicals are actively produced by live cultures of this species and have a maximal impact when contact or close proximity exists between live cells of $C$. polykrikoides and the target algae. These results are all consistent with our previous investigations of the toxic effects of C. polykrikoides on fish and shellfish larvae using the same cultures of $C$. polykrikoides and treatments (Tang \& Gobler 2009a,b). This consistency strongly suggests that, unlike other harmful algae whose well-known animal-killing toxins and allelochemicals are not identical (e.g. the paralytic shellfish toxin-producer Alexandrium spp.: Tillmann \& John 2002, Tillmann et al. 2007, 2008a; the brevetoxins-producer Karenia brevis: Kubanek et al. 2005), agents produced by C. polykrikoides which are toxic to fish, shellfish, and shellfish larvae are also responsible for the allelopathic effects to other phytoplankton. Therefore, C. polykrikoides may provide another case to the short list of HAB species that have been proven to have a common mechanism for their toxicity to animals and allelopathic effects on phytoplankton (Karlodinium veneficum and Prymnesium parvum: Granéli \& Hansen 2006, Tillmann et al. 2008b). The consistency between allelopathic experiments, fish bioassays, 
bivalve bioassays, and bioassays of shellfish larvae and the non-specificity of allelopathic effects on all microalgae tested suggests that labile, ROS-like chemicals are the allelopathic agents in C. polykrikoides, although further studies are needed to confirm this hypothesis.

It has been previously suggested that elevated $\mathrm{pH}$ values in mixed cultures of donor and target species might be responsible for the observed allelopathic-like effects in some HABs (Schmidt \& Hansen 2001, Lundholm et al. 2005). However, the lack of significant differences among $\mathrm{pH}$ levels in cultures of Cochlodinium polykrikoides, target species (i.e. no difference), and mixed cultures in the present study demonstrated that $\mathrm{pH}$ shock or $\mathrm{pH}$ increase during co-culturing was not responsible for the allelopathic effects of C. polykrikoides. Moreover, the presences of nitrate at levels more than an order of magnitude above the saturation constant for growth of C. polykrikoides (Gobler et al. unpubl. data) suggests that nutrient limitation would not account for the dramatic and prompt results we obtained (e.g. $>90 \%$ cell lysis in target species in $\leq 24$ h; Fig. 2).

\section{Ecological implications of the allelopathic effects}

The production of allelopathic chemicals is a strategy used by harmful algae to outcompete other, co-existing phytoplankton (Smayda 1997, Granéli \& Hansen 2006, Tillmann et al. 2008b), and our results demonstrate that this strategy likely plays a role in the occurrence of Cochlodinium polykrikoides blooms. In cultures, $C$. polykrikoides is a slow-growing alga $\left(\mu=0.4 \mathrm{~d}^{-1}\right.$; Tang pers. obs.) compared to other diatoms and dinoflagellates, including Gymnodinium instriatum and Akashiwo sanguinea (Smayda 1997), which bloom in the estuaries of New York prior (1 to $4 \mathrm{wk}$ ) to C. polykrikoides blooms or coexist with C. polykrikoides at high densities during bloom initiation (Gobler et al. 2007, Tang \& Gobler pers. obs.). Given this disadvantage in growth, C. polykrikoides must rely on other mechanisms, such as allelopathy to form mono-specific blooms. Since $C$. polykrikoides causes dramatic mortality in planktonic grazers, including bivalve larvae (Tang \& Gobler 2009b), planktivorous fish (Tang \& Gobler 2009a), and zooplankton (Jiang et al. 2009), grazer deterrence is another process that likely contributes to bloom formation. Allelopathic effects on competitors, together with grazing deterrence, could promote C. polykrikoides blooms through positive feedback (Sunda et al. 2006), whereby higher C. polykrikoides cell densities yield fewer competitors and predators, which, in turn, facilitates higher cell densities. Since the allelopathic effects of C. polykrikoides on co-occurring algae depend on absolute and relative cell abundances, allelo- pathy is more likely to contribute toward bloom maintenance when cell densities are high, than to bloom initiation when cell densities are low. The ability of $C$. polykrikoides to form localized areas of high cell densities by diurnal migration (Gobler et al. 2008, Kudela et al. 2008), however, could facilitate a scenario whereby C.polykrikoides could have allelopathic effects on competing algae, even during bloom initiation. In light of the conclusions of Putnam \& Tang (1986), Smayda (1997), and Tillmann et al. (2008b), further confirmative studies identifying C. polykrikoides allelochemicals and/or toxins and in situ measurements of allelopathic agents and their bioactivity are needed to clarify the role of allelopathy in C. polykrikoides blooms, particularly during bloom initiation.

Acknowledgements. We acknowledge support from the Suffolk County Department of Health Services, Office of Ecology and the New Tamarind Foundation. We thank N. S. Fisher for supplying cultures of Isochrysis galbana, Rhodomonas salina, and Thalassiosira weissflogii. We also thank Dr. Alejandra M. Marcoval, Ryan Wallace, and Courtney Blankenship for technical assistance.

\section{LITERATURE CITED}

Anderson DM, Burkholder JM, Cochlan WP, Glibert PM and others (2008) Harmful algal blooms and eutrophication: examples of linkages from selected coastal regions of the United States. Harmful Algae 8:39-53

Anton A, Teoh PL, Mohd-Shaleh SR, Mohammad-Noor N (2008) First occurrence of Cochlodinium blooms in Sabah, Malaysia. Harmful Algae 7:331-336

> Arzul G, Seguel M, Guzman L, Erard-LeDenn E (1999) Comparison of allelopathic properties in three toxic Alexandrium species. J Exp Mar Biol Ecol 232:285-295

Azanza RV, David LT, Borja RT, Baula IU, Fukuyo Y (2008) An extensive Cochlodinium bloom along the western coast of Palawan, Philippines. Harmful Algae 7:324-330

Bricelj VM, Shumway SE (1998) Paralytic shellfish toxins in bivalve molluscs: occurrence, transfer kinetics and biotransformation. Rev Fish Sci 6:315-383

> Buskey EJ (2008) How does eutrophication affect the role of grazers in harmful algal bloom dynamics? Harmful Algae 8:152-157

Cerrato RM, Caron DA, Lonsdale DJ, Rose JM, Schaffner RA (2004) Effect of the northern quahog Mercenaria mercenaria on the development of blooms of the brown tide alga Aureococcus anophagefferens. Mar Ecol Prog Ser 281: 93-108

Curtiss CC, Langlois GW, Busse LB, Mazzillo F, Silver MW (2008) The emergence of Cochlodinium along the California Coast (USA). Harmful Algae 7:337-346

Doblin MA, Blackburn SI, Hallegraeff GM (1999) Growth and biomass stimulation of the toxic dinoflagellate Gymnodinium catenatum (Graham) by dissolved organic substances. J Exp Mar Biol Ecol 236:33-47

> Fistarol GO, Legrand C, Granéli E (2003) Allelopathic effect of Prymnesium parvum on a natural plankton community. Mar Ecol Prog Ser 255:115-125

> Fistarol GO, Legrand C, Selander E, Hummert C, Stolte W, Granéli E (2004) Allelopathy in Alexandrium spp.: effect 
on natural plankton community and on algal monocultures. Aquat Microb Ecol 35:45-56

Gárate-Lizárraga I, López-Cortes DJ, Bustillis-Guzrnán JJ, Hernández-Sandoval R (2004) Blooms of Cochlodinium polykrikoides (Gymnodiniaceae) in the Gulf of California, Mexico. Rev Biol Trop 52:51-58

Gobler CJ, Deonarine SN, Leigh-Bell J, Downes Gastrich M, Anderson OR, Wilhelm SW (2004) Ecology of phytoplankton communities dominated by Aureococcus anophagefferens: the role of viruses, nutrients, and microzooplankton grazing. Harmful Algae 3:471-483

- Gobler CJ, Norman C, Panzeca C, Taylor GT, SañudoWilhelmy SA (2007) Effects of B-vitamins (B1, B12) and inorganic nutrients on algal bloom dynamics in a coastal ecosystem. Aquat Microb Ecol 49:181-194

> Gobler CJ, Berry DL, Anderson OR, Burson A and others (2008) Characterization, dynamics, and ecological impacts of harmful Cochlodinium polykrikoides blooms on eastern Long Island, NY, USA. Harmful Algae 7:293-307

Granéli E, Hansen PJ (2006) Allelopathy in harmful algae: A mechanism to compete for resources? In: Granéli E, Turner JT (eds) Ecology of harmful algae. Ecological studies, Vol 189. Springer-Verlag, Berlin, p 189-201

Granéli E, Johansson N (2003) Increase in the production of allelopathic substances by Prymnesium parvum cells grown under N- or P-deficient conditions. Harmful Algae 2:135-145

Guzmán HM, Cortes J, Glynn PW, Richmond RH (1990) Coral mortality associated with dinoflagellate blooms in the eastern Pacific (Costa Rica and Panama). Mar Ecol Prog Ser 60:299-303

Hallegraeff GM (1993) A review of harmful algal blooms and their apparent global increase. Phycologia 32:79-99

$>$ Hegaret H, Wikfors GH, Shumway SE (2007) Diverse feeding responses of five species of bivalve mollusc when exposed to three species of harmful algae. J Shellfish Res 26: $549-559$

Heisler J, Glibert P, Burkholder J, Anderson DM and others (2008) Eutrophication and harmful algal blooms: a scientific consensus. Harmful Algae 8:3-13

- Iwataki M, Kawami H, Mizushima K, Mikulski CM and others (2008) Phylogenetic relationships in the harmful dinoflagellate Cochlodinium polykrikoides (Gymnodiniales, Dinophyceae) inferred from LSU rDNA sequences. Harmful Algae 7:271-277

> Jiang X, Tang YZ, Lonsdale DJ, Gobler CJ (2009) Deleterious consequences of a red tide dinoflagellate Cochlodinium polykrikoides for the calanoid copepod Acartia tonsa. Mar Ecol Prog Ser 390:105-116

Jonsson PR, Pavia H, Toth G (2009) Formation of harmful algal blooms cannot be explained by allelopathic interactions. Proc Natl Acad Sci USA 106:11177-11182

Kim HG (1998) Cochlodinium polykrikoides blooms in Korean coastal waters and their mitigation. In: Reguera B, Blanco J, Fernandez ML, Wyatt T (eds) Harmful algae. Xunta de Galicia and intergovernmental oceanographic commission of UNESCO, Paris, p 227-228

Kim CS, Lee SG, Kim HG, Jung J (1999) Reactive oxygen species as causative agents in the ichthyotoxicity of the red tide dinoflagellate Cochlodinium polykrikoides. J Plankton Res 21:2105-2115

Kubanek J, Hicks MK, Naar J, Villareal TA (2005) Does the red tide dinoflagellate Karenia brevis use allelopathy to outcompete other phytoplankton? Limnol Oceanogr 50: 883-895

Kudela RM, Ryan JP, Blakely MD, Lane JQ, Peterson TD (2008) Linking the physiology and ecology of Cochlodi- nium to better understand harmful algal bloom events: a comparative approach. Harmful Algae 7:278-292

Legrand C, Rengefors K, Fistarol GO, Granéli E (2003) Allelopathy in phytoplankton - biochemical, ecological and evolutionary aspects. Phycologia 42:406-419

> Lundholm N, Hansen PJ, Kotaki Y (2005) Lack of allelopathic effects of the domoic acid-producing marine diatom Pseudonitzschia multiseries. Mar Ecol Prog Ser 288:21-33

Margalef R (1961) Hidrografía y fitoplancton de un área marina de la costa meridional de Puerto Rico. Invest Pesq 18:33-96

Marshall HG (1995) Succession of dinoflagellate blooms in the Chesapeake Bay, USA. In: Lassus P, Arzul G, Erard-Le Denn E, Gentien P, Marcillou-Le Baut M (eds) Harmful marine algal blooms. Lavoisier, Paris, p 615-620

McGillicuddy DJ, Anderson DM, Lynch DR, Townsend DW (2005) Mechanisms regulating large-scale seasonal fluctuations in Alexandrium fundyense populations in the Gulf of Maine: results from a physical-biological model. DeepSea Res II 52:19-21

Mulholland M, Morse R, Boneillo G, Bernhardt P, Filippino K, Procise L, Blanco JL (2009) Understanding causes and impacts of the dinoflagellate, Cochlodinium polykrikoides, blooms in the Chesapeake Bay. Estuaries Coasts 32: 734-747

Muller CH (1966) Role of chemical inhibition (allelopathy) in vegetational composition. Bull Torrey Bot Club 93: 332-356

Paerl HW (1988) Nuisance phytoplankton blooms in coastal, estuarine, and inlet waters. Limnol Oceanogr 33:823-847

Pitcher GC, Calder D (2000) Harmful algal blooms of the southern Benguela Current: a review and appraisal of monitoring from 1989 to 1997. S Afr J Mar Sci 22:255-271

Prince EK, Myers TL, Kubanek J (2008) Effects of harmful algal blooms on competitors: allelopathic mechanisms of the red tide dinoflagellate Karenia brevis. Limnol Oceanogr 53:531-541

Putnam AR, Duke WB (1974) Biological suppression of weeds: evidence of allelopathy in accessions of cucumber. Science 185:370-372

Putnam AR, Tang CS (1986) The science of allelopathy. Wiley, New York, NY

Qi D, Huang Y, Wang X (1993) Toxic dinoflagellate red tide by a Cochlodinium sp. along the coast of Fujian, China. In: Smayda TJ, Shimizu Y (eds) Toxic phytoplankton blooms in the sea. Amsterdam, Elsevier, p 235-238

Rice EL (1984) Allelopathy, 2nd edn. Academic Press, New York, NY

Richlen ML, Morton SL, Jamali EA, Rajan A, Anderson DM (2010) The catastrophic 2008-2009 red tide in the Arabian Gulf region, with observations on the identification and phylogeny of the fish-killing dinoflagellate Cochlodinium polykrikoides. Harmful Algae 9:163-172

Schmidt LE, Hansen PJ (2001) Allelopathy in the prymnesiophyte Chrysochromulina polylepis: effect of cell concentration, growth phase and pH. Mar Ecol Prog Ser 216:67-81

Silva ES (1967) Cochlodinium heterolobatum n. sp.: structure and some cytophysiological aspects. J Protozool 14:745-754

Siqueria JO, Nair MG, Hammerschmidt R (1991) Significance of phenolic compounds in plant-soil-microbial systems. Crit Rev Plant Sci 10:63-121

Smayda TJ (1997) Harmful algal blooms: their ecophysiology and general relevance to phytoplankton blooms in the sea. Limnol Oceanogr 42:1137-1153

Solé J, Estrada M, Garcia-Ladona E (2006) Biological control of harmful algal blooms: a modeling study. J Mar Syst 61: 165-179 
Sunda WG, Granéli E, Gobler CJ (2006) Positive feedback and the development and persistence of ecosystem disruptive algal blooms. J Phycol 42:963-974

Tang YZ, Gobler CJ (2009a) Characterization of the toxicity of Cochlodinium polykrikoides isolates from Northeast US estuaries to finfish and shellfish. Harmful Algae 8: 454-462

Tang YZ, Gobler CJ (2009b) Cochlodinium polykrikoides blooms and clonal isolates from the Northwest Atlantic coast cause rapid mortality in multiple species of bivalve larvae. Mar Biol 156:2601-2611

Tillmann U (2003) Kill and eat your predator: a winning strategy of the planktonic flagellate Prymnesium parvum. Aquat Microb Ecol 32:73-84

Tillmann U, John U (2002) Toxic effects of Alexandrium spp. on heterotrophic dinoflagellates: an allelochemical defense mechanism independent of PSP toxins. Mar Ecol Prog Ser 230:47-58

Tillmann U, John U, Cembella AD (2007) On the allelochemical potency of the marine dinoflagellate Alexandrium ostenfeldii against heterotrophic and autotrophic protists. J Plankton Res 29:527-543

Tillmann U, Alpermann T, John U, Cembella A (2008a) Allelochemical interactions and short-term effects of the dinoflagellate Alexandrium on selected photoautotrophic and heterotrophic protists. Harmful Algae 7:52-64

Editorial responsibility: Otto Kinne,

Oldendorf/Luhe, Germany
Tillmann U, John U, Krock B, Cembella A (2008b) Allelopathic effects of bioactive compounds produced by harmful algae. In: Moestrup $\varnothing$ et al. (eds) Proceedings of the 12th international conference on harmful algae. International society for the study of harmful algae and intergovernmental oceanographic commission of UNESCO, Copenhagen, p 12-18

Tomas CR, Smayda TJ (2008) Red tide blooms of Cochlodinium polykrikoides in a coastal cove. Harmful Algae 7:308-317

Turner JT, Tester PA (1997) Toxic marine phytoplankton, zooplankton grazers, and pelagic food webs. Limnol Oceanogr 42:1203-1214

Whyte JNCI, Haigh N, Ginther NG, Keddy LJ (2001) First record of blooms of Cochlodinium sp. (Gymnodiniales, Dinophyceae) causing mortality to aquacultured salmon on the west coast of Canada. Phycologia 40:298-304

Yamasaki Y, Nagasoe S, Matsubara T, Shikata T, Shimasaki Y, Oshima Y, Honjo T (2007) Growth inhibition and formation of morphologically abnormal cells of Akashiwo sanguinea (Hirasaka) G. Hansen et Moestrup by cell contact with Cochlodinium polykrikoides Margalef. Mar Biol 152: 157-163

Yamasaki Y, Shikata T, Nukata A, Ichiki S and others (2009) Extracellular polysaccharide-protein complexes of a harmful alga mediate the allelopathic control it exerts within the phytoplankton community. ISME J 3:808-817

Submitted: November 23, 2009; Accepted: February 10, 2010 Proofs received from author(s): April 27, 2010 